\title{
ARISTOTLE AND DEMOCRACY ${ }^{1}$
}

\section{INTRODUCTION}

There are two main types of question which arise from Aristotle's treatment of democracy, as from all other major topics which we find in that part of the Politics which is related to empirical data about political behaviour (Books 2-6 in O.C.T.). One type is primarily philosophical: 'Is Aristotle's analysis logically coherent, is it consistent with his data, is it convincing?' The other is more historical, though it has philosophical importance too: 'From where does he derive his data, from where his views (or prejudices)? Has he done justice to the historical events that he adduces and to the opinions of men that he cites as evidence for political and ethical norms?' Although in this paper I have a special interest in questions of the second type regarding the nature of the data, they cannot be tackled satisfactorily without considering the nature and validity of the analysis of democracy.

This, I think, corresponds to Aristotle's own methods in Politics 2-6. Although in these books he is not constructing an ideal constitution of his own, but analysing the merits and defects of constitutions that exist or have existed, this is not a purely empirical enquiry about what political arrangements have worked best in city $X$ or city $Y$. To be sure, he is not only seeking the best possible constitution, but also the best constitution possible in the light of a city's circumstances, in particular its social and economic basis (he stresses this on two important occasions in Book 4$1288 \mathrm{~b} 21 \mathrm{ff}$. and $1296 \mathrm{~b} 13 \mathrm{ff}$.). It is also true that he buttresses his general statements about human behaviour by examples taken from history. However, it is ultimately in the light of general ethical and political principles that the range of constitutions is judged.

Aristotle takes from history piecemeal what helps to substantiate his own beliefs, by making brief references, which are, as it were, footnotes in the middle of the page. We have no way of telling in many cases whether he has given a fair interpretation of a historical episode and some examples are disconcerting-for example his attribution of the secession of Mytilene from Athens in 428 B.C. to a personal quarrel over heiresses, in which the Athenian proxenos deliberately stirred up Athenian

\footnotetext{
1 General bibliography: W. L. Newman's commentary (4 vols. Oxford, 1887-1902) is still indispensable for its introductions, comments on points of detail (including historical allusions) and cross-references. The revised Oxford translation (J. Barnes, ed., The Complete Works of Aristolle, The Revised Translation, ii, Princeton, 1984) has been re-edited with a helpful introduction by S. Everson (Aristotle: the Politics, Cambridge Texts in the History of Political Thought, 1988). A Companion to Aristotle's Politics (ed. D. Keyt and F. D. Miller, Jr., Oxford, 1991 ) is a collection of essays which provides a valuable commentary on many themes touched on here, see especially chs. 11,13 and 14. Other modern accounts of Aristotle's treatment of democracy may be found in R. G. Mulgan, Aristotle's Political Theory (Oxford, 1977, 19872), chs. 4 and 6, and J. B. Morrall, Aristotle (London, 1977), ch. 6. Note also E. Braun, 'Die Extreme Demokratie bei Polybios und bei Aristoteles', JOeAl 54 (1983) Beiblatt, 1-40; C. Farrar, The Origins of Democratic Thinking (Cambridge, 1988), pp. 266ff. on Aristotle's hostility to democracy; T. Irwin, 'Moral Science and Political Theory in Aristotle', Crux (ed. P. A. Cartledge and F. D. Harvey, History of Political Thought, vi.1/2, Exeter, 1985), pp. 150-68, on the integration of Aristotle's ethical beliefs within his political analysis and especially (pp. 163ff.) on his inaccurate account of the characteristic vices of democracy.

A version of this paper was originally delivered in a seminar series at Oxford on 'Philosophy and History: Plato and Aristotle'. I am grateful to those who commented on it and to other contributors to the series.
} 
hostility to Mytilene (5.1304a4ff.) - something that we would not have guessed from Thucydides. ${ }^{2}$

Nevertheless, although we may be suspicious of the accuracy of individual historical items he cites, or question their validity as instances of a general phenomenon, the problems he confronts in the Politics largely arise from human experience and so do many of the solutions offered: the objects studied in the Politics are thus on the whole empirical, even if the values by which Aristotle judges them are his own theoretical construct. With regard to democracy this produces a special tension. Even if the Athenaiōn Politeia was not actually written by him but by a pupil (who adapted or garbled some of the statements in the Politics), ${ }^{3}$ he was well acquainted with the Athenian constitution of his own day-not only the constitutional details, but the principles underlying them (cf. 6.1317a40ff.) - and he details in the Politics a historical account of the development of the Athenian democratic constitution $(2.1274 \mathrm{~b} 35 \mathrm{ff}$.), which in fact he almost certainly accepts as true. His hostility to the 'extreme' democracy characteristic of Athens from the time of Ephialtes (2.1274a7ff., 4.1292a4ff., 1298a28ff., 6.1319b1ff.) appears at many points from his preliminary classification of constitutions $(3.1279 \mathrm{a} 21 \mathrm{ff}$.) onwards. Yet there is a coincidence between a major principle of this democracy, that of 'ruling and being ruled in turn' $(6.1317 \mathrm{~b} 2)$ and Aristotle's own belief that a city should involve the participation of all its citizens in government $(2.1261 \mathrm{a} 22-1261 \mathrm{b6}$, cf. $3.1275 \mathrm{a} 22-1275 \mathrm{~b} 21$ - the argument used in reverse to define the nature of the citizen). Furthermore, Aristotle produces a strong argument for majority rule among the citizens, in so far as their collective decisions in an assembly are based on a greater quantity of wisdom than that of a few experts $(3.1281 \mathrm{a} 40 \mathrm{ff}$.).

What I would like to show here is, first, how Aristotle's theoretical approach to democracy and his practical experience of democracy have become intertwined, and secondly, how in spite of his hostility to 'extreme' democracy as a constitution, certain features of Athenian democratic experience have influenced him positively, even if those derive less from his immediate experience than from traditions about Athens' past; it is this which makes his treatment of democracy more understanding and appreciative than we would expect. There is always in the Politics the problem of how far Aristotle is expounding his own view, how far giving a run to other people's ideas. It will, I hope, become clear that his argument for majority decisions is powerful and that, although he initially distances himself from the first account he gives of the development of Athenian democracy - a decline from a golden age in Solon's time --, he ultimately endorses this view himself.

\section{THE THEORY OF DEMOCRACY}

\section{(a) The definitions of democracy and oligarchy}

Our starting-point must be Aristotle's taxonomy of constitutions, found first in Nicomachean Ethics (8.1160a31ff.) and then in Politics (3.1279a21-b19). In the Ethics Aristotle lists, in order of preference, the good constitutions of monarchy, oligarchy and politeia (the last of which is said to be his preferred term for what is more

Thuc. 3.2-5; 10-14. Cf. A. Lintott, Violence and Civil Strife in the Classical City (London, 1982), pp. 105-6, 241.

${ }^{3}$ For a discussion of various arguments relevant to this question see P. J. Rhodes, $A$ Commentary on the Aristotelian Athenaion Politeia (Oxford, 1981), Introduction, esp. pp. 10-15, 58ff. Note also what seems to be a misunderstanding of Pol. 5.1303a in Ath. Pol. 26.1 and the rather clumsy interpretation of the doctrine in Pol. 3.1274a7ff. and 5.1304a20ff. to be found in Ath. Pol. 23.1 and 25.1. 
commonly called timokratia), followed by the bad constitutions of democracy, oligarchy and tyranny. Democracy is there the least bad of the second group and not far removed from politeia, but oligarchy and tyranny are characterised by the pursuit of private interest rather than the common good. The two triads reappear in the Politics, but here, while the 'correct' constitutions have the common good as their aim, all the 'deviations' (parekbaseis) are said to neglect koinōnia, community or partnership, in favour of allowing the rulers to pursue their own interests. In the bad triad of tyranny, oligarchy and democracy, the first is characterised by the despotism of one ruler, the second by the power of the wealthy and the third by the power of the poor, who pursue the interest of the poor.

An immediate problem arises in the Politics over the related definitions of oligarchy and democracy (3.1279b20ff.). Suppose that a majority (plethos) rule, when they are wealthy, or conversely that a minority rule, who are poor. Such societies apparently cannot be defined at all according to Aristotle's terms, or their definitions involve a contradiction. Aristotle here takes a firm position. For him the fact that the 'many' have power in a democracy and the 'few' in an oligarchy is an incidental factor. The real difference lies in the contrasting ideologies of the two constitutions. In oligarchy wealth is the criterion for status, in democracy the possession of freedom, which is the asset of all citizens including the poor $(1279 \mathrm{~b} 34-80 \mathrm{a} 6)$. Both rich and poor, in Aristotle's view (1280a16-25, cf. 5.1301a25ff.), make the mistake of overgeneralising their appreciation of their own status: in oligarchies the rich think that because they are unequal (that is, superior) in one respect, i.e. wealth, they are unequal in all respects; in democracies the poor think that because they are equal in one respect, freedom, they should be equal in all respects.

When Aristotle is dealing with the 'correct' constitutions, the number of rulers is the fundamental criterion. However, in his discussion of the deviant ones in the Politics, he abandons this criterion, when speaking of oligarchy and democracy, so discarding a neat theoretical parallelism in order to explain more satisfactorily how oligarchy and democracy deviate from the norm of the pursuit of the common interest and how these two constitutions are antitheses of each other. In other words he is pointing out that these two constitutions are based on the pursuit of two opposed class-interests, something which reflects the perception of oligarchic and democratic behaviour in the Greek world since the mid-fifth century (cf. $4.1296 \mathrm{~b} 22 \mathrm{ff}$. with its Thucydidean echoes). ${ }^{4}$

The reason that Aristotle gives for rejecting the oligarchic perception of society (1280a25ff.) is that it entails a view of koinonia which is based on wealth, like a business partnership. If the purpose of those who joined in a city was merely living, or mutual defence (summachia) or the protection of economic exchanges in order to avoid injustice, then the oligarchic view, according to which the status of the participant depended on his contribution in resources, would have some force, since society would be no more than a guarantor for the protection of the participants' just interests. However, it is a different matter if the purpose of a city is happiness and moral life or, to put it another way, to make citizens good and just. This is what characterises the true polis and differentiates it from an alliance of peoples according to a sunthēke (compact) or a geographical conglomerate. ${ }^{5}$ It is beginning to appear

4 Lintott [n. 2], chs. iii-viii, esp. pp. 90ff., 242ff. A more theoretical treatment is G. E. M. de Ste. Croix, The Class Struggle in the Ancient Greek World (London and Ithaca, 1981), with particular reference to Aristotle at pp. 69-80 and to the classical Greek city at pp. 278-300.

5 For the fundamental importance of koinonia in Aristotle's politico-ethical theory, which provides a different basis for rights than the state-of-nature ethical 'atomism' of Locke and his 
that Aristotle's conception of the city as a community conceived for the active pursuit of the good life not only has negative implications for oligarchy, but may have positive implications regarding democracy. One may relate to this the part of the discussion in Book $2(1261 \mathrm{a}-\mathrm{b})$, where he argues against Plato that a city is of its nature a diversity, and hence that it is preserved by reciprocal equality and by the participation of all in turn in government - a principle which he recognises in Book 6 as a major feature of democracy. Thus two different ethical arguments tend to suggest that the true polis is a species of democracy, even if this is not the democracy based on class-interest already classified as a deviant constitution. ${ }^{6}$

This becomes clearer in the discussion in Book 3, following that about koinonia, which concerns the sovereign body in the city. Aristotle begins with a typical oligarchic nightmare: 'Well then, suppose the poor divide up the wealth of the rich through being a majority, isn't that unjust?' 'No', they will say, 'for it was the just decision of the sovereign body' (1281a14ff.). After arguing that such a move would destroy the city and is therefore unjust, Aristotle nevertheless advances the view (1281a40ff.) that it is better for the masses to be sovereign than the best men, who are few, on the ground that a large assembly, by pooling its understanding and virtue, is morally superior and more intelligent than a small group of good men - just as they are better judges of music and drama. It is clear that the spoken and unspoken assumptions of Athenian public life have strongly influenced Aristotle. We may compare the view that Plato attributes to Protagoras (Prot.322d-323a), that all Athenian men have a share in virtue (aretē), or that which Thucydides attributes to the Syracusan Athenagoras (6.39.1), that the many are best at judging when they have listened. In fact, Aristotle rapidly puts in a caveat: what he has said does not apply to every mass of people (how indeed do some masses differ from beasts?); yet it is true of some. He then suggests a compromise: the masses should have a share in deliberation and judicial work, as Solon laid down. For one thing it is dangerous to prevent them participating (1281b27ff.); for another, even if they have not the knowledge characteristic of a man with a special skill (technē), they may judge better as users and consumers (1282a14ff.). It should be noted that because in the assembly the mass are acting as a collective, this justifies their being assigned power, which it would be inappropriate to give to their members as individuals.

One further argument deserves notice. In the discussion of justice, which arises out of this, the issue is whether certain members of the community deserve unequal rights because of some superior capacity (1282b14ff.). Aristotle seeks to show that all claims advanced by certain classes in society for an unequal share in office and power on account of their superiority in one respect may be subverted. One can neither decide which form of superiority should be decisive, nor transfer superiority from one field to another, nor make superiorities in different fields commensurable. This rules out claims for preference in office by the well-born, or the landowners, for example (1283a31ff.). A somewhat different argument applies to the masses (plethos) and the few (1283b23-35). If the mass claims to rule through having superior power, this factor may equally justify rule by a few or a single man. Conversely, if certain men claim to rule on account of virtue or wealth, the mass as a whole may be more wealthy or virtuous than they.

followers, see S. Everson, 'Aristotle on the Foundation of the State', Political Studies 36 (1988), 89-101. Of course the idea that a community is simply some kind of compact or alliance was already current in Greece, as Aristotle points out at 1280b10ff., cf. Keyt in Keyt and Miller [n. 1], pp. 252-3. For the concept of 'atomism' see C. Taylor, Philosophy and the Human Sciences. Philosophy Papers 2 (Cambridge, 1985), ch. vii.

Everson [n. 5], p. 90 n. 2. 
Two things emerge from these preliminary discussions of democracy. First, it follows logically from Aristotle's conception of the polis that the plethos, the mass of citizens, has a part to play in running a city. Secondly, Aristotle takes it to be a matter of fact that the mass tends to pursue its class interest, and not that of the community as a whole, unless it is restrained. It is because of this that he lists democracy as a deviant constitution and he introduces the conception of a politeia as a constitution where the mass rules but pursues the interest of the city as a whole (1279a37-b3). He argues that it is difficult for a majority of a city's population to be virtuous in every respect, but this can be found in relation to military virtue. Hence it follows that in a politeia the sovereign power is the armed forces. It looks as if at this point Aristotle has adapted and renamed the concept of timokratia, the qualified democracy of property-holders (cf. $E N$ 8.1160a33-6), who are also hoplite soldiers, so that it may embody the theoretical virtues of democracy. ${ }^{7}$ In this way he can extract himself from some of the contradictions into which his views on democracy are leading him.

\section{(b) Variants of democracy: the social basis}

In Book 4 Aristotle sets out to discuss his politeia and the three deviant constitutions with two standards in mind, the ideal and that which is contingent on the circumstances of the city and, so to say, customer-oriented. Aristotle makes it clear at the start that the basic categories of city-constitution are in themselves inadequate bases for analysis. Cities vary according to their social composition, and this affects which constitution should be chosen either by them themselves or by a legislator working on their behalf (1289b27ff.). Later, societies as a whole are analysed into different classes - such as the farmers, artisans, warriors and the deliberative class, as well as the rich and poor - on the understanding that these elements are the variables, whose conjunction in differing forms creates the varieties of city, just as differing physical organs in conjunction create different animals (1290b21-1291b13).

Democracy is here classified as the most moderate of the bad constitutions (4.1289b2ff.), as in the Ethics (8.1160b7ff.). (The view of Plato (Politicus 302a ff.) that there could be a good form of all constitutions and democracy was the worst of these, but the best of all the bad forms, is rejected, on the ground that there cannot be good forms of bad constitutions). The definition of democracy (1290a30-b20) is consistent with the arguments of Book 3 (1279b-80a). It is not the rule of the mass (plēthos) (a majority of citizens rule even in an oligarchy): it is the rule of the free and poor, when they are in the majority. Varieties of democracy are analysed in more than one way. The common people (demos) itself is subdivided (1291b14-28) into classes such as the farmers (geórgoi), the craftsmen (to peri tas technas or banauson), the traders (to agoraion, to peri ōnen kai prasin diatribon) and those involved with the sea, like ferrymen and fishermen, merchants and warship-crews. It is implied that variations in the presence of these classes will produce different varieties of democracy.

Democracy is also classified (1291b30ff.) in a typology which follows a descending scale from the most preferable kind, 'which gets its name from equality'. By this Aristotle may mean isonomia, the term used for example by Herodotus in his staged

\footnotetext{
7 Politeiai based on hoplites had been proposed at Athens during the oligarchic revolutions of 411 and 404 (see e.g. Lintott [n. 2]. pp. 153f., 164f.) and apparently even after the restoration of democracy in 403 (Lysias 34). On the general argument in this passage see also W. von Leyden, Aristotle on Equality and Justice (Basingstoke, 1985), p. 17-25, stressing the qualitative differentiation between rich and poor and the arguments for democracy rather than rule by experts.
} 
debate about the relative merits of different constitutions. ${ }^{8}$ This preferable type of democracy is designed to hold the balance between rich and poor, so that neither rules the other. Decisions are by majority, but, it is implied, the power of the wealthy is entrenched in some way. This seems in some respects to correspond to the Cleisthenic constitution at Athens, that in force at the time of the Persian Wars, where, according to both Aristotle and the Athenaion Politeia, the influence of the Areopagus was maintained. ${ }^{9}$ The Ath. Pol. also tells us that, on the eve of the oligarchic revolution of 411 , Cleitophon proposed that a commission should study the laws of Cleisthenes, on the ground that they were more like the ancestral constitution (see below, p. 123, 125-126). ${ }^{10}$ Aristotle himself does not clearly characterise Cleisthenes' constitution in the Politics. ${ }^{11}$

Of the other types on Aristotle's descending scale, the second has offices based on property-qualifications, though these are small; the third allows all citizens who are anupeuthunoi (not liable to trial) to hold office (4.1292a2). ${ }^{12}$ In this kind of democracy the law is said to be sovereign. The same is true of the fourth type, where the whole citizen body is allowed office. Finally, there is the type of democracy where not the law, but the mass (plēthos), is sovereign, that is, where psēphismata override nomos. This occurs because of demagogues. Lawful democracy does not give scope for a demagogue, but the best of the citizens preside over it. This democracy, by contrast, because it is not ruled, becomes a tyrannical monarch itself (1292a4-38). ${ }^{13}$

Aristotle clearly intends this type of democracy to represent what is essentially corrupt about democracy. It is at first sight surprising that he lays such stress on the loss of the sovereignty of nomos. For earlier (3.1281a34ff.), he has suggested that the sovereignty of law does not eliminate class-strife: laws themselves may have oligarchic or democratic tendencies. This discussion reflects the debate in Athens over

${ }^{8}$ I differ from the Oxford translation here and hence, in my interpretation, from Mulgan (in Keyt and Miller [n. 1], pp. 307-22 at 318f.), at least in part. Mulgan rightly compares 6.1318a3ff., where Aristotle refers to what seems to him to be the most democratic democracy, in which the poor have no more share of government than the rich, but then argues that this type of democracy is less moderate than the second type where magistrates are required to have a small property-qualification. I do not see how this follows, since a small property-qualification (such as the opening of the archonship at Athens to all but the thetes in Pericles' time of ascendancy) would not have entrenched the share in government of the rich. On isonomia see Hdt. 3.80.6, 142.3; 5.37.2; cf. Thuc. 3.82.8; 4.78.2-3; LGS 447, 450 (Athen. Deip. 15.695a-c); M. Ostwald, Nomos and the Beginnings of Athenian Democracy (Oxford, 1969), pp. 149-58; G. Vlastos, 'Isonomia Politike' $\bar{e}$ ' ISONOMIA : Studien zur Gleichheitsvorstellung in griechischen Denken, ed. J. Mau and E. G. Schmidt (Berlin, 1964), pp. 1-35.

${ }^{9}$ Pol. 3.1274a7ff.; 5.1304a20ff.; Ath. Pol.23.1; 25.1. Although 1 accept Vlastos' [n. 8] powerful argument that isonomia denotes an egalitarian ideal ('a banner rather than a label') only properly realised by democracy, I believe it possible that Aristotle was influenced here by the tendentious use of the term for regimes which were not fully democratic but aspired to equality on their own terms (cf. Isoc. Pan. 178; Areop. 60-1; Thuc. 3.62.3-4). See also M. H. Hansen, The Athenian Democracy in the Age of Demosthenes (Oxford, 1991), pp. 65-71 for an account of Aristotle's typology of democracy and a critique of the view that isonomia was the original official term for democracy. 10 Ath. Pol. 29.3.

${ }^{11} \mathrm{He}$ only refers to the tribal refom $(6.1319 \mathrm{~b} 21 \mathrm{ff}$.) and the enfranchisement of metics (3.1275b35ff.).

${ }_{12}$ The Oxford translation renders anupeuthunoi 'under no disqualification'. Newman (vol. iv ad locc) compared $1292 \mathrm{a} 2$ with $1292 \mathrm{~b} 35$, from which it appears that we must supply in the first passage 'kata to genos' (" in respect of their birth'). The term presumably refers to people not actually deprived of citizen rights but to whom objection might be made (the sort of people discussed in Ath. Pol. 13.5 \& 21.2 ). Hence Aristotle is assuming that a stricter birth-qualification might be applied to officers of the city than to members of the assembly.

${ }^{13}$ Newman appropriately compared the speech addressed to the character Dêmos in Ar. Knights $1111 \mathrm{ff}$. 
the sovereignty of a single meeting of the assembly (ekklessia). Aristotle seems to be endorsing the constitution of the democracy after its refoundation in 403 , with which he was directly acquainted, where indeed nomoi could not be overthrown by simple decisions of the ekklessia, but could only be rescinded or supplemented by a commission of lawgivers, whose conclusions were assessed in the popular law-court (dikastērion). However, he himself does not draw any distinction between fifth- and fourth-century democracy here, and in a later passage (1298b28ff.) he specifically states that his most extreme form of democracy is the one currently in use in Athens. ${ }^{14}$ He should have been particularly opposed to the practice of the age of Thucydides, where there were inadequate safeguards against the assembly taking the law into its own hands. The classic example of this was the trial of the generals after the battle of Arginousai in $\mathbf{4 0 6}$ by procedure devised ex tempore, which was put into effect after threats against any who tried to obstruct it - both speakers and the presidents of the assembly. The one president who persisted unsuccessfully in resistance was Socrates. ${ }^{15}$

These grades of democracy are, at least in part, related to the possession of supreme power by certain classes (1292b25ff.). Democracy according to law is associated first with the supremacy of the farmers and those possessing a moderate amount of property (because the farmers have to work, they only attend the minimum number of assemblies required). But it is also possible when ultimate power lies with those with irreproachable descent or even with all free men, provided that only those who have the requisite leisure participate and there is no state revenue to support them without their having to work. However, in the final category (1292b41ff.), where the city is large and prosperous, all men share in citizenship on account of the supremacy of the masses and participate because they receive pay and so can afford time off work.

Once again, the influence of Athenian history is patent. Aristotle takes as one of his criteria an important feature of Athenian democracy from the time of Pericles onwards - one much attacked by democracy's critics. The elimination of pay (misthos) was central to the oligarchic programme of 411 and this part of the programme was reaffirmed by the 'moderate' constitution of 5,000. After the convulsions of the late fifth century, pay was once again a feature of fourth-century democracy and its scope and quantity were extended. ${ }^{16}$ For Aristotle misthos, it seems, is dangerous on two grounds: it attracts the wrong kind of person to the assembly and it makes him a dependant of the demagogues.

Aristotle goes on to talk briefly about the politeia (1293b22ff.). This is now depicted as a mixture of oligarchy and democracy, with the proviso that people in fact apply the term to mixtures which tend to the democratic, while those tending to the oligarchic are called aristocracy. This general definition is amplified by an exposition of how through different modes of operation this constitution may become a composite (1294a30ff.). One method is to combine the standard precepts of oligarchy

14 Nomothesia is likewise not mentioned in Ath. Pol., unless it was in the lost section at the end after the discussion of voting in the law-courts. Instead, the author (41.2) stresses the retention of sovereignty by the demos, whether it was operating through the assembly or lawcourts. Basic sources for the nomothesia procedure are Dem. 24.20-3, 38; Aesch. 3.38-40, cf. M. H. Hansen, The Sovereignty of the People's Court in Athens in the Fourth Century B.C. (Odense, 1974); Id. The Athenian Assembly in the Age of Demosthenes (Oxford, 1987), pp. 98, 174. 15 Xen. Hell. 1.7.9ff.; Plato, Apol. 32a-b.

16 Agyrrhios reintroduced assembly-pay at 1 obol a day, Heracleides of Clazomenai raised it to 2 obols and Agyrrhios raised it again to 3 (Ath. Pol. 41.3). All this occurred between 403 and the production of Ar. Ecc. (393-390 B.C.), cf. lines 289-311, 392. Later, before Ath. Pol. was written, the rate was raised to 9 obols at the main assembly in each prytany and 6 obols at other assemblies (62.2). 
and democracy. Oligarchies force the wealthy to undertake jury-service through fines; democracy encourages the poor to be jurors through pay, but does not fine the wealthy; the politeia will have both fines and pay. A second mode of creating a politeia is through seeking a mean by virtue of an assembly based on a moderate propertyqualification (not one too large or too insignificant). A third mode is by mixing institutions. It is democratic to have office assigned by lot rather than by election; it is oligarchic to have a property qualification. A politeia will thus have election to offices without a property-qualification. ${ }^{17}$

So far it has been established that democracy is a form of constitution, in which the poor rule in their own interest; that there are varieties of this according to the particular class of poor people who are dominant; that there are also grades of democracy, which depend on the relative importance of nomos (established law) against psēphismata (individual decrees) and the extent of participation in the assembly - i.e. the existence of a de iure property-qualification or a de facto propertyqualification through the lack of political pay and the need for members to stay at work. The importance of established law will affect in particular the relation of magistrates to the assembly.

Much later in Book 4 Aristotle introduces a further form of differentiation (1298a9ff.) in his discussion of the three main features of any constitution - the nature of the deliberative body, the mode of election of officials, the nature of the judicial body. The democratic principle is that everyone should deliberate about everything, but there are various methods by which this can be achieved. One is a system of rotation, such as in the constitution devised by Telekles the Milesian and other constitutions, where on the basis of tribes and other very small divisions, everyone takes office in turn and the assembly only meets to establish laws or constitutional procedures or to hear the instructions of those in office. In a second system the primary assembly only meets for elections, legislation, decisions on peace and war and the audits of officials, while other matters are left to the officials chosen by lot or election from the whole citizen-body. A third is similar in principle, but most dayto-day business is to be handled by officials, who are to be elective as far as possible, especially when expertise is required. Only the fourth system reserves all deliberation for the assembly and allows officials no capacity to decide but only to make preliminary examination of issues. 'This', adds Aristotle, 'is the way that the final democracy is now organised, a way which we claim to be analogous to dynastic oligarchy (i.e. a narrow oligarchic junta) and tyrannical monarchy.'

\section{(c) The essential characteristics of democracy}

The most detailed account of democratic institutions occurs in a long excursus in Book 6 (1317al6ff.). Aristotle's main theme here is how constitutions may be safeguarded. His justification for the digression is that there are more varieties of democracy than one (not only as the result of the varieties of démos but also through the varied combinations of democratic features) and the correct and expedient methods must be applied to each.

Aristotle sets out here both principles (hypotheseis) and then typical democratic institutions and behaviour. The chief principle (1317a40) is liberty (eleutheria), which is analysed into two sub-principles, the first of which is ruling and being ruled in turn - something which Aristotle advocated in general as a characteristic of the true polis

17 The opposite - officers chosen by lot from those qualified by wealth - is $A t h$. Pol.'s version (8.1) of the Solonian constitution, but Pol. $3.1273 \mathrm{~b} 40$ and $6.1319 \mathrm{a} 29$ insist that officers were elected. 
back in Book 2 (1261a-b). Here he argues that, since democratic justice is based on numerical equality rather than equality according to worth, the majority decision must be authoritative and this must constitute what is just. This is not an exhaustive definition of ruling and being ruled in turn in a democrat's eyes: it does not cover the allotment of offices to the citizens, discussed below, but it alludes to one aspect of it. The citizen in the assembly may help to make laws and must abide by them. Another sub-principle (1317bl lff.) is that of living as one wishes. This, Aristotle maintains, on a popular view is the realisation of freedom, in so far as living contrary to one's wishes is characteristic of a slave. By contrast with the first, this feature of democratic ideology has already been dismissed by Aristotle as bad in Book 5 (1310a30ff.), on the ground that it threatens the survival of the constitution. ${ }^{18}$

The practices that support these principles (1317b17ff.) are: first, that all elections should be by the whole citizen-body and that candidates should be drawn from the whole citizen-body; secondly, that all rule each and each rules all in turn; thirdly, that all offices which do not require a particular knowledge or skill should be selected by lot; fourthly, that offices should not require a property-qualification or at least only a minimum property-qualification; fifthly, that men should repeat the same office as little as possible, except in war-time, and these offices should last as short a time as possible; sixthly, the jurors should be the whole citizen-body, or a selection of the whole citizen-body, in all matters or at least the most important; seventhly, the assembly should be in charge of all or most matters, the officials of none or as little as possible (in democracies, where there is not money to pay everyone, the council is the most democratic of all the official bodies); finally, there should be pay for all, members of the assembly and courts and officials, or, failing that, for the courts, the council and plenary assemblies, or for the officials that are required to eat together. All these practices contribute to ruling and being ruled in turn in a democratic fashion. By contrast Aristotle gives no detailed example of living as one wishes.

That Aristotle has seized on the chief features of democracies, as they were understood by men who lived and were political leaders in them, can be shown by a comparison with Thucydides' version of the funeral speech of Pericles. According to this, demokratia gets its name because it is organised not for the few but the majority. Pericles stresses equality for the citizen as an individual and the absence of a property qualification for office, thus the basis for 'ruling in turn' according to the Aristotelian formulation. He simultaneously points to the liberty in private life: the Athenians, he claims, did not put pressure on individuals to conform to social norms. ${ }^{19}$ Moreover, the Athenians were obedient to magistrates and laws. Here we have 'being ruled in turn', the other half of Aristotle's doublet. If the principles of democracy, as Aristotle

18 The notion of acting as one pleases is something of a caricature and can hardly be predicated of behaviour in any Greek city, however democratic. Plato regards it as a characteristic of the democratic man in Rep. $8.557 \mathrm{~b}$, cf. $560 \mathrm{e}, 9.572 \mathrm{e}$. Isocrates uses similar phrases (Areop. 20; Pan. 131) to denounce current democracy by comparison with the good old days of Cleisthenes. Cf. Newman, iv. 496. Nevertheless there is a democratic principle here which works in an apparently contrary sense to that of ruling and being ruled in turn. See Hdt. 3.83.2, where, after the debate staged between the Persian conspirators, the protagonist of democracy Otanes says 'I want neither to rule nor be ruled', also the allusion to personal freedom in the Funeral Speech, discussed below. For the importance of personal or private liberty within the democratic concept of eleutheria see the excellent discussion by Hansen [n. 91], pp. 73-81, emphasising the similarities, rather than the differences, to modern views of individual rights.

${ }_{19}$ Thuc. 2.37 (organisation for the benefit of the majority is what Aristotle calls to dikaion to dèmotikon $-1317 \mathrm{~b} 2$ ). Ruling in turn and equality before the laws are also claimed as democratic principles in a text contemporary with the Funeral Speech (Eur. Supp. 404 8, 429-34). 
understood them, are essentially Pericles', the majority of practices detailed - such as the domination of the assembly and pay for participants - conform to those of Athenian democracy and are evidently intended to represent the extreme type of democracy.

\section{(d) The preservation of democracy}

Aristotle's recipe for preserving this type of constitution - a form of loaded voting in strict proportion to wealth (1318a27ff.) - is somewhat bizarre and it is difficult to take it too seriously, though the problem is a genuine one on his assumptions: if the existence of the classes of rich and poor is considered to be an inevitable datum for the legislator, then in order to avoid class-conflict, he has to create some kind of democratic equality between rich and poor. It would have been interesting to know Aristotle's view on the form of voting, loaded in favour of wealth, found in the Roman comitia centuriata.

Aristotle then returns to the other forms of democracy (1318b6ff.), beginning with his own preference, the form first listed in his catalogue and the most ancient effectively, the Athenian constitution before the Persian Wars, as Aristotle understood it in the Politics, still following Solon's principles (cf. 2.1274a35-b21 and $3.1281 \mathrm{~b} 32-5) .{ }^{20}$ This was a constitution based on the farmers, who are content with a limited amount of government and are prepared to spend most of their time on their farms. All the citizens are permitted to elect the magistrates and participate in euthunai, where ex-magistrates are held to account, and in the courts. Magistracies have property-qualifications or are assigned to the capable, hoi dunamenoi (this term is close to dunatoi, the standard expression in Thucydides for the wealthy governing class). Thus the better sort are left to rule, but they will rule justly, because they are subject to audit for their activity in office. Dependence (to epanakremasthai) and the inability to do everything you want are in Aristotle's view a good thing - perhaps the first sign of the 'checks and balances' version of the theory of the mixed constitution (1318b38-9). ${ }^{21}$ As an appendix he recommends some of the ancient restrictions on landholding in order to create a citizen-body of farmers (1319a4-19).

His treatment of the other democracies is more sketchy $(1319 \mathrm{a} 39 \mathrm{ff}$.), but he does give his approval to measures such as were employed by Cleisthenes (1319b19ff.), that is, the creation of new tribes, in order to create political unity and thus bolster the extreme form of democracy. He also enters a plea for not making the proceeds of condemnations in the lawcourts available to the poor (1319b33ff.), in case it encourages demagogic prosecutors: this money should be saved. As we might expect,

20 Although Aristotle does not overtly endorse the approval of Solon's measures ascribed to some (enioi) in $3.1273 \mathrm{~b} 35$, it is transparent through the following account of Athenian democracy and the reader's impression there is confirmed by the present passage. It is worth noting that the election of magistrates is central to Aristotle's appreciation of the Solonian constitution. If we believe that the version in $A t h$. Pol. 8.1, according to which magistracies were assigned by lot to members of a preselected group, represents Aristotle's later view, this marks not merely a change of view about a historical problem but the abandonment of an article of faith. On reconstructions of Solonian democracy as charters for current democratic ideology see now M. H. Hansen, 'Solonian Democracy in Fourth-Century Athens', in Aspects of Athenian Democracy, ed. J. Rufus Fears ( $C$ \& $M$. Diss. xi, 1989), 71-99, emphasising the difference between the maximum interpretation, visible in Ath. Pol. and orators like Demosthenes, and the minimum view of Solon as a moderate democrat shared by Isocrates (esp. 7. Areop. 22-7, 36-57) and Aristotle.

21 On the difference between the Aristotelian concept of the mixed constitution and the later (Polybian, Ciceronian and early modern) 'checks-and-balances' theory see W. Nippel, Mischverfassungstheorie und Verfassungsrealität in Antike und früher Neuzeit (Stuttgart, 1980), esp. pp. 57ff., 142ff. 
he is generally wary about public payments to the poor (1320bl7ff.), unless there are prosodoi (i.e. an income like that of the Athenian empire). These should be kept to the minimum, where there is no money. Where there is, the legislator must realise that the poor are a 'leaking sieve' (1320b31-2), and so should avoid simple hand-outs, but produce funding for the acquisition of land or capital for farming or trade.

\section{ARISTOTLE AND DEMOCRATIC IDEOLOGY}

Aristotle's interpretation of democracy in Book 6 is based, first, on what actually happened at Athens (and to a greater or less extent happened in other democracies, about which we are not well informed, but who took Athens for their model), and, secondly, on an ideology that goes back at least to Thucydides' time of writing, one which was probably being expressly formulated for the first time from the $460 \mathrm{~s}$ onwards. He also talks about democracies where there was a greater balance between the classes in society $(4.1291 \mathrm{~b} 30 \mathrm{ff}$.) - something for which there was evidence in Athens' earlier history and indeed in other democratic cities. The ideology behind this balanced kind of constitution may be argued to be as old as Solon, who claims to have given the demos as much privilege as was sufficient (fr. 5 West). But it could certainly be found in the late fifth century, side by side with the Periclean interpretation, to judge from the speech that Thucydides gives to the Syracusan orator Athenagoras. He talks of the rich, the intelligent and the many, both in parts and as a whole having equal shares in democracy and rebukes the young politicians for not wanting to have isonomia with the many (6.39.1 and 38.5). For Athenagoras what is important is that the intelligent are encouraged to deliberate, so long as the many take the final decision. ${ }^{22}$

I have deliberately emphasised so far the positive aspects of Aristotle's attitude to democracy - his recognition of theoretical arguments in favour of it, his understanding of its distinctive features and the reasons for them. However, the basis of his negative attitude is also apparent. Although he knows about a form of democracy where class-interests are balanced $(4.1291 \mathrm{~b} 30 \mathrm{ff}$., cf. $6.1318 \mathrm{~b} 6 \mathrm{ff}$.), he believes that the forms of democracy which are most true to type are those which pursue the interests of the poor, and as such, are in direct antithesis to the typical forms of oligarchy (3.1280a7ff.). Typical too is that version of democracy, discussed at another point (4.1298 10 and 28-31), where all deliberation and decision-making are the function of the assembly and are in no case left to the magistrates, whether elected or otherwise selected.

Although Aristotle deploys arguments suggesting that decisions taken by the majority of the population may be wiser than those taken by an expert few (1281a40ff.), he is in practice reluctant to trust this decision-making, except on a few central issues (cf. 1298a11ff. for possible mechanisms for avoiding the full citizenbody deciding everything). He prefers a dēmos which only participates in assemblies to a limited extent (because it is occupied working on the land), especially when the alternative is a demos based on craftsmen, small traders or manual labourers. This is implicit in the analysis in Book 4 (1292b22ff.) and it is spelt out in Book 6 (1318b6ff., cf. 1319a 19ff.). The best form of democracy is that of the farmers; second-best is one based on herdsmen, because they are fit and warlike and, like the farmers, kept busy

${ }^{22}$ On the importance of the wealthy upper class in Syracusan democracy at the time of Athenagoras' speech see Lintott [n. 2], pp. 189ff. Aristotle believed that victory over Athens changed Syracusan society in the same way that victory over Persia changed Athenian (Pol. 5.1304a27ff.). 
with their livelihood. The democracies based on craftsmen, labourers and small traders are far inferior, because the livelihood of these classes does not involve virtue (1319a26) and enables them to be regular attenders at assemblies, because they are required to hang around the city. ${ }^{23}$

\section{ARISTOTLE AND ATHENIAN HISTORY}

It would be simplistic to attribute Aristotle's suspicion of democracy solely to the influence of Platonic doctrine. Although in Politics 7 and 8 Aristotle produces a sketch of a theoretical society similar in some respects to that proposed in Plato's Laws, he is prepared to distance himself from Plato when he thinks it appropriate over the community of property and wives proposed in the Republic (2.1261a), over the lack of concern for happiness in both Republic and Laws (1264b), over the impracticality of the state proposed in the Laws $(1265 \mathrm{a}-\mathrm{b})$ and the oligarchic bias in the constitution of the Laws (1266a).

It is more plausible to point to Aristotle's attitude to the poorer classes in the city, the small traders (agoraioi), the craftsmen (banausoi) and the labourers (thêtes) (3.1278a8ff.; 6.1319a26; 7.1329a19ff.; 1331a33ff.). They are free men and therefore cannot be treated as slaves; but Aristotle has the greatest reserve about their participation in the politeia, even in the main part of the Politics concerned with more practical problems. Is this not the prejudice of the educated intelligentsia against the uneducated? Not entirely: for it does not explain his preference for farmers and even herdsmen to the proletariat of the city (1318b6ff.). Nor for the same reason can it be merely snobbery towards those who have to work for a living: indeed part of the objection to the banausoi is that they can take time off work to vote in the assembly, when farmers cannot. His attitude seems to be closely connected with his interpretation of Athenian history - something, in my view, more sharply revealed in the Politics than in the somewhat confused reflection of Aristotelian opinions found in the Athenaion Politeia - an interpretation in which the demagogues are the villains and the banausoi their servile dupes (cf. 4.1292a4ff., b41ff.).

Aristotle's summary of the rake's progress of the Athenian constitution can be found in the section on lawgivers in Book $2(1273 \mathrm{~b} 21 \mathrm{ff}$.). He remarks that some people think that Solon was a good lawgiver, because he overthrew the excessively unmixed oligarchy, brought the slavery of the demos to an end and established the 'ancestral democracy' by an excellent constitutional mix. In this the Areopagus was oligarchic, election to office was aristocratic and the lawcourts democratic. In the view of some others the democratic lawcourts (being chosen by lot) were the mistake, as this element grew in power and everyone tried to win its favour, so creating the 'present' (i.e. fourth-century) democracy. Further, Ephialtes and Pericles cut down the Areopagus, while Pericles instituted paid jury-service and this was developed by subsequent demagogues into the 'present' democracy. This, in Aristotle's view, had not been Solon's intention, but resulted from the pride of the demos after the Persian Wars and its reception of bad demagogues, who opposed the decent men (epieikeis). ${ }^{24}$ For Solon only gave the demos the sine qua non of power through his system of property-qualification for office (Aristotle here paraphrases Solon's own words (fr. 5 West), 'I gave the dèmos as much privilege as is sufficient').

23 The elevation of the class of herdsmen is a remarkable thing in an ancient Greek writer. They figure little in our ancient sources and seem to be regarded as on the margin of civilisation, e.g. in Dio Chrys. Or. 7, cf. L. Robert, 'Bergers grecs', Hellenica 7 (1949), 152-60.

${ }^{24}$ In Ath. Pol. 25 the demagogues are Ephialtes and Themistocles, while in 26.1 the epieikesteroi have no leader but are championed by Cimon. 
Aristotle contrasts the Solonian constitution and its mixture of elements with what, he suggests, became more and more an undiluted democracy as time went on (interestingly he makes no mention of Cleisthenes in this context). In his implied acceptance of Solon's constitution here, Aristotle does not mention the social basis of the democratic element, but in the light of Book 6 (1318b6ff.) he must have believed it to have been the farmers. What is more important for him is that the assembly did not monopolise decision-making: elective officials had their part and so did the oligarchic council of the Areopagus.

\section{THE MESOI-A SOLUTION?}

We hear more of Solon in the discussion of what is the best constitution for most people (4.1295a25ff.), where it is argued that, just as for individuals virtue lies in a mean (EN 2.1106a14ff.), so it does for constitutions. According to this slightly strained analogy, hoi mesoi, the middle class (the term refers both to their property and their character in the Politics), are the best part of the city - reasonable, because free from violence and petty crime, and neither inclined to pursue office nor avoid it, whereas the other classes either desire to be despots over slaves (the attitude of the rich to the poor) or are willing to be slaves obeying masters (the attitude of the banausoi and agoraioi to the rich). "The result of this is a city of slaves and masters rather than of free men, with one class envious and the other scornful - characteristics which are far removed from friendship and political partnership' (1295b21ff.) language which is once again reminiscent of Solon (frs. 4 and 9). The mesoi by their very nature ensured that a city was ruled by the equal and alike (isoi kai homoioi), who were most suited to koinonia (partnership). Similarly, it was the mesoi who could prevent stasis (civil strife) by limiting the inequality of property and so preserve democracies for longer than usual, since the poor did not press their demands so much (1296a $7 \mathrm{ff}$.). The best lawgivers were from the mesoi (1296a $17 \mathrm{ff}$.). Solon was one of these (he made this clear in his poems), as were Lykourgos, Charondas and most of the others.

In fact the domination of the mesoi is a pipe-dream or a might-have-been for Aristotle. For he goes on to point out (1296b22ff.) that, on the whole, constitutions have been hijacked by the more powerful forces in the city, becoming oligarchies when the wealthy were dominant, democracies under the common people. This situation was reinforced by the policies of the leading states in Greece (by this he means Athens, Sparta and, in the fourth century, Boeotia), who favoured their own constitution, democratic or oligarchic, in other cities. This passage is reminiscent of a chapter in Thucydides' famous digression on stasis (3.82), in particular when Aristotle talks of the wealthy and the demos not establishing a common or equitable constitution but making dominance over it the prize (athlon) of their victory (1296b29-31, cf. Thuc. 3.82.8). It is also worth remembering that the concept of the mesoi appears in this same section of Thucydides (here called ta mesa tōn politōn): they were destroyed by both sides in stasis, either because they did not take sides or through envy at their survival. Aristotle concludes this passage (1296a38ff.) by saying that only one man among those formerly in a position of leadership was persuaded to deliver the moderate constitution (mesē politeia). In my view this was Solon. ${ }^{25}$

${ }^{25}$ Evidently, from what Aristotle has said, Solon is a prime candidate for fulfilling this description, since he was a moderate who produced a constitution which was a skilful mixture (above, p. 125). Newman preferred Theramenes (i.370; iv.220). The latter's claims are based on the 'constitution of 5,000', which Thucydides (8.97.2) called 'a moderate blend (metria 


\section{DEVIANCE AND DEMAGOGUERY}

Athenian democracy, then, is for Aristotle a deviant constitution in the precise sense that it had deviated from the balanced constitution which he associates with Solon. The latter at least approximated to one of the forms of the good constitution, the politeia - a term which in Aristotle's view was most properly applied to a mixed constitution created by blending features of oligarchy and democracy (1294a15-b41). Solon's constitution seems also to fit the definition of the most tolerable form of democracy, that connected with equality and community (129lb30). Moreover, Aristotle's portrayal of extreme democracy as one in which decrees (psēphismata) are authoritative, rather than law, on account of demagogues (1292a6ff.), is clearly connected with his belief that demagogues from Ephialtes onwards overthrew Solon's constitution (1274a5ff., cf. 1305a28ff.).

A further weakness of democracy in Aristotle's eyes is its vulnerability. Like Plato in Republic 8, Aristotle argued that democracy tended to induce tyranny through the activities of demagogues, who damaged the wealthy, either through accusations or through attacking their property directly by proposing a redivision of land or demanding free public services (leitourgiai) (5.1304b19-1305a 7 ). The interesting thing is that he develops two different strands in this interpretation. One (1305a7-27, cf. $1310 \mathrm{~b} 12-1311 \mathrm{a} 8$ ) is reminiscent of Plato's picture (Rep. 8.557a ff., 562a ff.) of the demagogue, who acquires such trust and such a political following from his attacks on the rich, that he becomes a tyrant himself. Aristotle seeks to substantiate this with the near-contemporary example of Dionysius I, who was Plato's prototype, and archaic instances, such as Peisistratos, Kypselos and Theagenes (the latter are very dubious evidence as none was a demagogue within an extreme democracy: at best, Peisistratos was a demagogue within Solonian democracy and could indeed be regarded as subverting Aristotle's canonisation of Solon's work). The second argument is that demagogues create tyranny by provoking a reaction from an oligarchic or tyrannical conspiracy (5.1304b19-1305a7, cf. 1310b9). Aristotle cites examples from Cos, Rhodes, Herakleia Pontica, Megara and Kyme in Ionia. This argument in some respects resembles the well-known debate staged by Herodotus, where three leading Persians discuss the merits of monarchy, oligarchy and democracy. The last speaker, Dareius, argues that democracies produce mischief (kakotēs) through conspiracies by the kakoi against the common interest, until one man becomes the leader of the people and puts an end to these conspiracies by becoming a monarch (3.82.4). Herodotus' monarchic leader is clearly not identical with Aristotle's monarchic or oligarchic conspiracy, inasmuch as he is a popular champion himself, even if he is not a demagogue. However, he performs a similar function in relation to the original leaders of the people. ${ }^{26}$

xunkrasis) in the power of both the many and the few' - an opinion which Aristotle may well have shared and interpreted as the promotion of the mesoi. However, we have no explicit statement in Aristotle to this effect, and the emphasis in this passage on one man points away from Theramenes, since both in Thucydides and Ath. Pol. (33.2) the constitution is said to be the work of Aristocrates as well as Theramenes. Any ruler or lawgiver contemporary with Aristotle is excluded by the contrast between 'formerly' and the second half of the same sentence, 'but even now those in the cities have developed the tendency...' .

${ }^{26}$ Cf. Lintott [n. 2], pp. 239-40, 249. It is a nice question whether Herodotus had some specific instance in mind. He may have been influenced by an earlier Sicilian tyranny, that of Gelon, who overthrew a democratic movement when he seized Syracuse in 486 (Hdt. 7.155-6). 


\section{CONCLUSION}

I have been trying to show that the anti-democratic sentiments in Aristotle have a much wider basis than either his own doctrine or Plato's and certainly go beyond simple aristocratic prejudice. They have a long pedigree, stretching back to Solon himself, and have an empirical grounding in a particular view of Athenian history. Some of the conclusions drawn from history seem unfair when applied to Athens. In spite of being by Aristotle's standards the worst form, Athenian democracy was remarkably stable: up to Aristotle's death there had been only two major upheavals, both in the late fifth century, one prompted by military failure, the other enforced through defeat. Nevertheless, many individual charges strike home. It was to a great extent true that the dēmos pursued its own class-interests, that demagogues from time to time pursued private interests rather than those of the community, that decisions were not always taken by those best qualified to do so and, in the fifth century, that immediate popular feeling could be exploited to override law. To a certain extent Aristotle resembles the fifth-century writer of the oligarchic essay on the Athenian constitution, found in the Xenophontic corpus. He understands in detail the elements which constitute democracy and appreciates their coherence, but abominates the result, that is, the facility provided by the demos to pursue its own interests. ${ }^{27}$

By the side of this powerfully buttressed distaste stands Aristotle's own politicoethical theory, his commitment to the polis as koinonia (partnership and community) in pursuit of happiness through the good life. He refuses to accept that a city could be merely an association for military or economic purposes, so that it could be run by a central authority, whether monarchic or oligarchic $(3.1280 \mathrm{~b} 17 \mathrm{ff}$.). The true citizen must be involved in the running of his own affairs (cf. 4.1295a25ff.; $7.1328 \mathrm{~b} 26 \mathrm{ff}$.): otherwise, if he is unable to take moral decisions not only as an individual, but as a member of the community, how can he achieve virtue?

If the democratic solution failed to produce koinonia, could Aristotle offer a better one? The political constitution of his Utopian city in Books 7 and 8 is too vaguely sketched to be of practical value. More convincing is his espousal of a Solonian constitution with its limits on participation. But history had shown that such a constitution was no more stable than extreme democracy; equally, it might be argued that it was insufficiently democratic to meet the requirements of true koinonia.

${ }^{27}$ [Xen]. Ath. Pol. 1.1-4 and passim. 